\title{
Run, ANDY, RuN
}

\author{
JULEE STILLMAN
}

ANDY HAD BEEN running all his life. From the moment he struggled to be born-his scrawny neck gripped in a strangle hold by his umbilical cordand looked up into his mother's hate-filled eyes, he'd been on the run.

As a little kid, he'd run away from home often. After each drug fuelled belting he fled, only to be taken home by the police.

'Found the little bugger hiding under the bridge again. Might be best if you put him in a home, Maggie. Got it too good here with you.'

On his return, Maggie - never call her Mum, not if you know what's good for you-would give him another belting. She'd lock him in the cupboard too if he didn't take it like a man. Andy could put up with that belting, it was only half-hearted; showed she loved him, Maggie said. The cuddle afterwards and the tear stained promises of trying to be a better mother, he couldn't bare. Besides, her promises never lasted long. A new man to fawn over, loud parties where he was told, 'Piss off, kid, you're not wanted here,' would find him under the bridge again.

He was there just after his twelfth birthday, shivering cold and scared of being taken home again, when he met Steve.

'What ya doin' here, kid? Shouldn't ya be home with ya mummy?'

'Piss off.' It felt good to say that. Andy curled his lip and said it again. 'Piss off.' 


\section{'What's ya name?'}

Andy sneered, 'What's yours?'

'Steve. Yours?'

'Andy. Andy Andrews.'

Steve stuck his hand out. 'Nice to meet you Andy Andrews. Shit, your parents hate you or what? Andrew Andrews. What a crack up.'

Andy, who hadn't given it much thought before, figured his mother was too lazy to think of anything original. Most of the time she never called him anything anyway, so what did it matter.

Steve knew everything there was to know about living rough, he told Andy, and what he didn't know wasn't worth knowing. 'Soup kitchen's down the road about a klick. Run by the Salvos. They're all right, don't preach or nothin'.'

Andy hated soup; watery horrid stuff with bits of carrot and, if his mother was in a good mood, the odd pea or two. 'So?'

'So, you comin' or not?'

Thick soup with chunks of pink ham had Andy moaning with delight. 'We doing this tomorrow night?' he asked.

'Not goin' home?'

Andy shook his head. 'Can't.'

'In that case,' Steve said, punching Andy's arm, 'we can. There's another one the other side of town too. I'll take ya there one day.'

For the next few years Steve, three years older and wiser and in charge, kept a look out while Andy stole everything from bread to blankets, radios to rugs; anything they could use or sell. As they ran from the cops, yelling out, 'Suckers,' over their shoulders, hearts thumping in their chests, Andy felt exhilarated. This was what life was all about. No need for a mother who couldn't give a damn one way or the other about him. No need for school; wouldn't do him any good anyway, 'too dumb' his mother said. No need to do anything he didn't want to.

When he was fifteen, his long legs outrunning Steve and the store-keeper, Andy slid under the bridge, arms full of stolen cigarette packets, and waited for Steve to catch up. He never did. Old Man said he'd been nabbed by the cops, but what did he know. Silly bugger was in his cups most of the time. 
'Live here with me if you want,' Old Man said as though he owned the rights to the bridge.

You could only stay here if Steve said so. Old Man seemed to have forgotten that. Moved his mouldy gear in a couple of days after Steve disappeared.

'Piss off.'

Old Man took a swig of gin. 'Here.' He thrust the bottle out. Andy waved it away. 'Suit yourself.'

'Probably metho anyway. Stupid bugger.'

Andy and Old Man shared the bridge on and off for the next few years. Old Man disappeared every now and then-paid government holiday - and came back slipping into his drunken ways again as if nothing had happened.

'Still here, then?' he'd say.

'Piss off.'

Down the pub one night, a sometime-mate told Andy about a job going at the wharf.

'Easy,' he said, 'don't have to do much and the pays good.'

The pay was good, but the perks were better. It didn't take Andy long before he had a nice little sideline in stolen goods. Within a year, he'd moved into a flat nearby-never gave Old Man another thought - recruited a couple of helpers, bought himself a battered old van, and branched out interstate. His sometime-mate didn't suspect a thing.

When Steve showed up-'Didn't Old Man tell ya I were in the slammer?'-Andy got himself another truck. He didn't pay for this one. With a new paint job, stolen number plates and the vehicle number erased with acid, no way the cops could trace it to the warehouse down the road. Steve did a great job. One of the many talents he'd learnt inside.

In his late twenties, Andy fell in love for the first time. Babs, a busty blonde with a ready sense of humour, was new to town. Came down from somewhere up country and ready for anything the Big Smoke offered. Willing to overlook his nefarious dealings, even helping by flogging the odd TV or two, she was his ideal woman. 
Babs and her mangy cat moved into the flat- 'He'll eat the mice, sweetie, he has to stay'-along with three suitcases of clothes, more books (books for God's sake) than the local library and vacuumed, dusted and cleaned until Andy no longer recognised the place.

When she came home with a green parrot who screeched all day long, Andy lost it. Babs had to choose; it was him or the cat and the bloody bird.

Loneliness ate at Andy like a toothache. After an agonising three days, he ran after her. When he finally tracked Babs down-tucked up nice and cosy at home with her parents, mangy cat and screeching bird in tow-he was mighty tempted to give her a good belting for his troubles. He raised his hand, started to swing, his mother's face egging him on, when Babs punched him in the mouth, splitting his lip and loosening a tooth.

'Ever do that again, Andy boy, and it'll be the last time you do anything.'

God, he loved that woman.

A new flat-two bedrooms with a little balcony overlooking the freeway-did them all fine until Babs announced, with a grin that looked a lot like the entry to Luna Park, she was pregnant. Bloody hell, stuff it, now he'd have to get yet another truck, hire more lads to drive - and take the fall if they got caught — and a bigger flat.

That wasn't good enough for Babs. She wanted a house, yard and all.

This time Andy ran. He left one thousand dollars on the kitchen bench, a note wedged under an empty beer bottle and hightailed it back to his comfort zone: the bridge.

Steve took pity on him and dragged him back to his squat. 'Never did like Babs,' he announced with authority. 'What did she think she was doin', goin' and gettin' herself pregnant like that? Silly bloody cow.'

When the baby was born, a girl named Crystal, Andy found himself in a right pickle. Part of him wanted to run back to Babs and Crystal, part of him wanted to run as far away as possible.

'Compromise,' Steve said.

Andy did. Every birthday, every Christmas, he spent with them. The rest of the year he ran from anything family orientated. Not that he didn't love Crystal- just that he wasn't cut out to be a 
father. Besides, he didn't have time for all that mushy stuff; he had a business to run.

Give Babs her due, she didn't say a bad word about Andy to Crystal and the girl grew up adoring him.

'Little blighter don't know enough to stay away, that's her problem,' Steve said.

Peeved, Andy shot back, 'Pearls of wisdom, is it Steve? Well you can keep them to yourself. The kid's okay.'

Crystal ran away at fourteen. Some geezer with a sports car and a fancy mouth promised her the world and off she went. Andy ran after her. She was more than happy to come home. The bloody paedophile had her in some flea-bitten hotel out back of nowhere. No shops, no nothing. No way to treat his kid.

The sports car, stolen - tut-tut-didn't look so nice after Andy finished with it. Nor did Geezer, not with snot and blood leaking from his broken nose.

'Play football?' Andy asked him.

'Yeah,' Geezer said, throwing his arm up to protect himself from another crushing blow.

'Which leg you kick with?'

Geezer didn't answer. Didn't have to. His eyes flew to his right leg. Big mistake. Andy broke it in three places.

After howls of pain-music to Andy's ears-Geezer puffed out, 'You just made the biggest mistake of your life, arsehole. I'm a cop. You're gone.'

'Nah, mate, I'm still here.' Andy giggled. Sometimes he could be a funny bugger.

When Crystal married a big-shot lawyer, Andy couldn't believe his luck. Fancy having a beak in the family. Could come in handy; bit of protection should anything go wrong.

Time to move into some heavy territory. The first job, a wholesale jewellers, went without a hitch. Two hundred thousand dollars worth of diamonds. Freddy the Fence, glad to handle anything Andy and the lads came up with. The second job went well; so did the third, fourth and fifth. 
Buoyed by his success, Andy planned the daddy of all heists.

Out in Craigieburn, the NPA printed banknotes. Andy's interest lay in the hundreds. No good taking the small stuff. May as well knock off the local supermarket if that's all you were after.

No matter which way he looked at it, Andy needed an inside man as well as someone who knew explosives and wouldn't blow the lads and the money to smithereens. A few days after putting the word out on the street, Andy had a business lunch at the local pub with a bruiser of a man.

'Been at the NPA years,' he told Andy. 'Not easy to get in. Harder getting out.'

'But it can be done?'

'Wouldn't be talking to you otherwise,' Bruiser said. 'And I know a guy who's handy with plastic.'

They hit late one Friday afternoon. Bruiser said that was the best time; they printed the hundreds on a Friday. Leaning against the side door of the van, Andy heard a deep rumble. Vault door open. Minutes later, Bruiser and the lads began stuffing bag after bag of money into the van. Fully loaded, Andy slammed the door shut. He'd see them back at the lockup.

'Hey? Arsehole?'

Ah, shit. Geezer. And the rotten bastard could run. Should've broken both his legs.

Andy heard a bullet whistle past his ear followed by Geezer yelling, 'Stop! Police!'

He heard nothing as a second and third bullet thudded into his back.

'Should've listened all those years ago, shouldn't you?' Geezer smiled as he stood over Andy. 'Told you then I was a cop. Told you then you were gone.'

Andy wheezed out his last breath.

'Piss off.' 